\title{
Performance Evaluation of SRI Funds: An Analysis of Fund Types
}

\author{
Halil Kiymaz ${ }^{1}$ \\ ${ }^{1}$ Crummer Graduate School of Business, Rollins College, 1000 Holt Avenue, Winter Park, FL 32789, USA \\ Correspondence: Halil Kiymaz, Crummer Graduate School of Business, Rollins College, 1000 Holt Avenue, Winter \\ Park, FL 32789, USA, Tel: 1-407-646-2267. E-mail: hkiymaz@ rollins.edu
}

Received: January 21, 2019

Accepted: February 21, $2019 \quad$ Online Published: February 22, 2019

doi:10.5430/afr.v8n1p212

URL: https://doi.org/10.5430/afr.v8n1p212

\begin{abstract}
Socially responsible investing (SRI) continues to be a popular topic for both practitioners and academicians as the demands for these funds increased sharply during the last decade. This study provides additional evidence on performance of SRI funds. The empirical findings provide mixed evidence as SRI funds experience lower average returns relative to various benchmarks and provide higher risk adjusted returns relative to some of the benchmarks. Among the subgroups analyzed, SRI Fixed Income funds offer the highest risk adjusted returns to investors while SRI Global funds provide the lowest returns. Finally, using Jensen's alpha for individual funds, we find that about half of the funds experience negative alphas and 18 percent of SRI funds have statistically significant negative alphas compared to 7 percent of funds with that of positive alphas. Overall, the findings show mixed evidence concerning SRIs performance.
\end{abstract}

Keywords: funds, socially responsible fund, responsible investment, SRI

\section{Introduction}

There is increasing literature suggesting the SRI may produce superior performance compared to conventional investing. The social and ethical investments have become an essential development in the finance world over the last few decades. The levels of awareness for the social issues that affect the quality of their lives have increased drastically. For example, people have a better understanding of health hazards associated with smoking and hence have distanced themselves from tobacco products, including disinvesting firms that produce them.

Although social investing is an old phenomenon going back many centuries, modern social investing is a new concept. The social investing typically reflects the concerns of investors on topics like environmental degradation, exploitation of workers, human rights abuses, among others. These investors argue that companies should be accountable for their actions in these areas. Thus, fund managers consider various criteria in forming their portfolios as the demands for socially responsible funds have increased. For example, retail investors can make socially responsible investments in individual firms or through a socially conscious mutual fund or exchange-traded fund (ETF). Mutual funds and ETFs provide an added advantage in that investors can gain exposure to multiple companies across many sectors with a single investment. For example, the Social Investment Forum (2018) reports the total net assets of funds integrating socially responsible criteria to their investment decisions increased to $\$ 12$ trillion in 2018.

The primary question is whether the firm's objective of shareholder wealth maximization is consistent with the socially responsible behavior that society expects from a firm. Finance theory tells us the primary goal of a firm is to maximize the shareholders' wealth as reflected in the market value of the shares. A reasonable argument is that firms are unable to advance the environment without adversely affecting shareholder value. Any funds used to improve the environment is cost to a firm, and thus force firms increase product prices or accept profits. On the other hand, some researchers (i.e. Schueth, 2003) argue that investment in social and environmental issues can increase a firm's efficiency and potentially create new markets.

SRI is green investing that is considered socially responsible because of the nature of the business the company conducts. That is, investors limit their investment alternatives to securities of firms whose products or actions are considered socially acceptable. For example, socially responsible investments might avoid investments in companies that produce or sell addictive substances (such as tobacco, liquor products, or gambling) and might seek out companies engaged in environmental sustainability and alternative energy or clean technology efforts. The 
primary question of the SRI studies is whether the SRI funds perform better or worse than traditional investment funds without restricted investment universe.

Some question whether investors sacrifice performance for the sake of ideology. That is, just because an investment touts itself as socially responsible does not mean that it will provide investors with a good return. Another question of whether active portfolio management investing in socially responsible firms can produce better performances is an unresolved issue. Jarrow (2010) argues that persistent and frequent arbitrage opportunities are rare and excess returns are more of fantasy than fact. Lin, Hoffman, and Duncan (2009), on the other hand, contend that with skilled managers, a higher alpha can be achieved without added risk.

This purpose of this study is to examine the performances of SRI in mutual funds using various risk adjusted benchmarks to provide additional evidence. This study contributes to the literature the following ways: First, it uses a larger sample of SRI funds than previous studies with an extended time-period. Second, it provides evidence on six different styles of the fund, ranging from Domestic Equity to Global funds. Third, it uses four risk adjusted return measures and compares the performance of SRI funds in each group with their benchmarks. Finally, it provides an analysis of Jensen's alpha using individual fund performance.

The findings show SRI funds have lower unadjusted returns relative to their benchmark indexes, but the difference is statistically insignificant. Using several risk adjusted measures, we find that SRI funds perform better than two of the benchmarks but underperform the remaining three benchmarks. When we examine the risk adjusted performance of subgroups of the funds, we note that the SRI Fixed Income funds provides the highest risk adjusted returns, followed by SRI Equity, SRI Institutional funds. SRI Global funds provides the lowest risk adjusted returns during this period. Using Jensen's alpha on individual funds, we find that only 7 percent of funds have statistically significant positive alphas while 18 percent of funds experience statistically significant negative alphas.

The paper is organized as follows. In section 2, we define the SRI and briefly explain inclusion or exclusion criteria for SRI. We also demonstrate the theories associated with the performances of SRI. Section 3 provides a literature review of the empirical studies. Section 4 describes the data selection and method used. In section 5 the empirical findings on the performance of SRI funds and indices are reported. The last part concludes the study.

\section{What is Socially Responsible Investing?}

A typical definition of socially responsible investing includes an application of nonfinancial screening to a universe of investments to identify potential investment opportunities. For example, Kinder and Domini (1997) define social screen as expressing an investor's social, ethical, or religious concern in a form that allows an investment manager to apply it in the investment decision-making with other screens. Schueth (2003) defines socially responsible investing as the method of mixing personal values and societal concerns into investment decision-making. A standard definition of responsible investing describes it as an investment process in which sustainability criteria about a company's social and environmental behavior plays a decisive role in admitting that company's stocks to the investment portfolio.

While SRI decisions involve both positive and negative investment screens, fund managers use multiple screenings. Majority of fund managers use negative screening that refers to excluding certain groups of stocks or industries from SRI portfolios based on social, environmental, and ethical criteria. For example, alcohol, tobacco, and gambling represent the most common restrictions that SRI investors use. These restrictions include exclusion from investing in manufacturers, distributors, and retailers of such products. Besides these restrictions, investment in military contracting and weapons producers is also used often. Similar arguments apply to nuclear power plants and firms that design, supply parts, and provide services. Other negative screens may include adult entertainment, genetically adjusted organisms, violation of human rights, and animal testing.

Positive screening, on the other hand, highlights the positive characteristics of investments. For example, the firm's community involvement, sensitivity to the environment, diversity, employee relations are used often for positive screening. Firms generous giving and support for education reflects its strong commitments to their community. Environmental issues may include involvement with recycling, pollution prevention, and use of alternative fuels.

The primary question for investors is the impact of these screenings on the return performance and the risk of investment. Any screening would reduce the number and types of investible alternatives so investors' ability to diversify across firms may disappear. So, social screening may create uncompensated risk. Modern portfolio theory suggests that diversification reduces the total risk in a portfolio, suggesting that a positive or negative screening might result in a lower risk adjusted return to the investors. On the other hand, this reasoning may not hold because negative filtering may also remove lower-return stocks because of their business or industry characteristics. 
Would the performances of socially responsible funds be the same as conventional funds? The literature provides three important theories: The first theory is there is no significant difference between the risk adjusted expected returns of SRI funds and traditioanl portfolios. This theory would suggest that any value adding social responsibility behavior is not reflected in stock prices. Further, investors cannot adjust their risk requirements, as they usually fail to recognize the differences in the cost of capital.

The second theory contends the expected returns of socially responsible portfolios are lower than the expected returns of conventional portfolios. This would show that applying social screens might increase a firm's risk as these screens may limit the full diversification potential of the fund. So, it could shift the mean-variance frontier towards less favorable risk-return trade-offs than those of conventional portfolios. For instance, excluding parts of the stock market, such as firms producing alcohol, tobacco, and pornography, may negatively influence the risk-return trade-offs of SRI funds. There are several studies providing support for this theory. Among them, Grossman and Sharpe (1986) report that a portfolio without South African stocks a higher standard deviation relative to the New York Stock Exchange (NYSE) index. Also, removing a portion of the total universe of stocks may result in suboptimal portfolios and imposing ethical constraints on the equity investment will cause inferior portfolio performance. Applying social screening in portfolio forming could also increase in volatility, reduced diversification, and create other costs associated with the screening. Bauer, Derwall, and Roger (2007) explain the rational for this theory. They contend that an ethical investment opportunity set is a subset of the entire investment universe. Developing and monitoring social screens may be an expensive practice and, therefore, can be a drain on net return. Adler and Kritzman (2008) also argue the cost of responsible investing is substantial for even moderately skilled investors.

The final theory argues that returns from socially responsible investments provide higher yields than conventional counterparts do. This theory points out that evaluating potential investments with financial and social screens makes good social and economic sense. Using positive filters for investment has two advantages. First, investment decisions are in line with their values, and socially responsible investors will pressure firms that are nonresponsive to social concerns. For example, Konar and Cohen (2001) report that bad environmental performance is inversely related to the intangible asset value of firms. For example, a 10 percent decrease in emissions of toxic chemicals results in a \$34 million increase in market value. Yamashita, Sen, and Roberts (1999) find the release of information on a company's environmental conscientiousness affects stock prices positively. Waddock and Graves (1997) argue that corporate social performance is positively related to the firm's previous financial performance.

Similarly, Goldreyer, Ahmed, and Diltz (1999) also find socially responsible funds employing inclusion screens outperformed the sample that did not use such screens. The second advantage of socially responsible firms may be that they are financially stronger and more profitable because they will be less likely to be subject to product liability suits and settlements, with environmental fines and lawsuits (Sauer, 1997). Also, Reyes and Grieb (1998) and Hickman, Teets, and Kohls (1999) display that socially responsible screens may be valuable contributors to portfolio risk reduction and so could potentially provide economic benefits to investors.

\section{Literature Review}

Many studies examine the returns of SRI funds and indices. There are two opposing views on the economic viability of socially responsible investing. Empirical studies (Sauer, 1997; Guerard, 1997; Waddock \& Graves 1997; Konar \& Cohen 2001; Statman, 2006; among others) report conflicting results about the superiority of socially responsible investing. Several of earlier studies focus on the performance of indices. The first group of studies reports the dominant performance of SRI indices over the conventional index. For example, Grossman and Sharpe (1986), Diltz (1995), Hutton, D'Antonio, and Johnsen (1988), Luck and Pilotte (1993), and Heyes (2005) find socially responsible indices (i.e. Domini Social Index (DSI)) outperform traditional index (i.e. S\&P 500). Statman (2000) also reports the DSI performed better than S\&P500 and socially responsible mutual funds did better than traditional mutual funds during 1990 and 1998 period but the difference between risk adjusted returns were not statistically significant. Lyn and Zychowicz (2010) find that faith-based funds perform better than other SRI funds and market index based on Sharpe and Treynor measures. Schröder (2004) points out that most of the German, Swiss, and US SRI investment funds do not significantly underperform their benchmarks. Among international studies, Luther, Matatko, and Corner (1992) and Mallin, Saadouni, and Briston (1995) also report that on a risk adjusted basis ethical trusts outperform the nonethical trusts.

There are also many studies not finding any significant differences in returns of SRI and conventional portfolios. Guerard (1997), Kurtz (1997), DiBartolomeo and Kurtz (1999), and Corson and Van Dyck (1992) do not find any statistically significant difference between returns of socially screened and unscreened portfolios. Blanchett (2010) 
provides a mixed result about the performance of SRI funds relative to non-SRI funds. While SRI funds underperform non-SRI funds in pure returns, the risk adjusted SRI fund performance is dominant.

International studies reporting no significant differences SRI and conventional funds include Luther and Matatko (1994) and Gregory, Matatko, and Luther (1997) for U.K. and Tippet (2001) for Australia. Moreover, Kreander, Gray, Power, and Sinclair (2005) extend the U.K. matched pair approach for fund evaluation developed by Mallin et al. (1995) to a European setting and report no difference between ethical and nonethical funds on their performance. More recently, Ayadi, Ben-Ameur, and Kryzanowski (2016), using Canadian SRI funds, also reports no differences in performance of these funds with respect to non-SRI funds. Further, neither types of fund displayed any ability to time the market.

Besides analyzing the performances of SRI indices, many studies also examine the returns of SRI mutual funds. Among them, Hamilton, Jo, and Statman (1991) provide empirical evidence on performances of 32 socially responsible mutual funds relative to a conventional benchmark. The results show that social responsibility factors do not affect expected returns or cost of capital. Statman (2000) also reports no significant differences between socially responsible funds and conventional funds, although the socially responsible mutual funds performed better than traditional funds of equal assets size. Sauer (1997) also finds that application of social responsibility screens does not impact investment performance adversely.

Gil-bazo, Ruiz-verdú, and Santos (2010) analyze SRI mutual funds based on the contributions of before-fee performance and fees to SRI funds' performance. SRI funds earn a premium regarding superior risk adjusted performance relative to that of similar conventional funds both before and after fees. The superior performance of the SRI funds concerning traditional funds is caused by the operation of these funds by management companies that specialize in managing SRI funds. This study for investors implies that they should consider management company characteristics when selecting SRI funds.

Fowler and Hope (2007) find the returns of socially responsible investments have either underperformed, or failed to outperform, compared with market indices. SRI screens for equities do not lead to a significant performance difference compared to conventional investments. While it may seem, the screening should lead to a decline in the risk adjusted return, the results from this analysis showed the SRI stock indices do not display a different risk adjusted return than their conventional benchmarks. However, many SRI indices have a higher risk relative to their benchmarks.

Bauer, Koedijk, and Otten (2005) review the performances of a group of ethical mutual funds. By applying a multifactor Carhart (1997) model and controlling for investment style, the authors find little evidence of significant differences in risk adjusted returns between ethical and conventional funds. The introducing time-variation in betas however leads to a statistically significant underperformance of domestic US funds and outperformance of U.K. ethical funds, relative to their conventional peers. Finally, they provide evidence on learning the effect of these funds. While older ethical funds seem to be catching up with conventional funds, younger funds continue to underperform both the index and peers.

More recently, Belghitar, Clark, and Deshmukh (2017) and Nakai, Yamaguchi, and Takeuchi (2016) examine the SRI fund performance in U.K. and in Japan during the global financial crises. While the former study finds that the SRI funds perform better in pre-and post-financial crisis, the latter study suggests that SRI funds better resisted the bankruptcy of the Lehman Brothers than conventional funds.

The results of academic research on the performance of the SRI funds are mixed. While many studies report weak evidence of a difference in risk adjusted returns between ethical and conventional funds, other studies find that SRI funds can be a valuable source of portfolio risk reduction, even for investors who are not driven by social values. On the other hand, some researchers report a statistically significant cost associated with socially responsible mutual fund investing. Some argue that the research is inconclusive as the different conclusions can largely be explained by the faulty method, and further inquiry into the matter is recommended. This research aims to provide more evidence on the performance of SRI funds.

\section{Data and Methodology}

Socially responsible investment fund data is obtained from the Morningstar database. The list of funds is from the Social Investment Forum and USSIF. In Table 1 reports the sample selection process. The initial sample consisted of 202 SRI funds. The funds with no data or fewer than 12 months of observation were removed, leading the final sample of 152 SRI funds. About half of these funds were classified as Domestic Equity funds (67 funds), followed by Institutional funds (34) funds, and Global funds (20 funds) in the sample. The sample also included Balanced funds 
(17 funds) and Fixed Income (14 funds). The study period spans from January 1995 to May 2015.The reported benchmark index is identified and used as the market portfolio for each fund. These benchmarks include S\&P 500 Index, Russell 2000 Index, Russell 1000 Index, Barclays US Aggregate Bond Index, and MSCI World Index.

Table 1. Sample selection

\begin{tabular}{lllll}
\hline & $\begin{array}{l}\text { Initial } \\
\text { sample }\end{array}$ & $\begin{array}{l}\text { Funds with no data or less } \\
\text { than 12 months of data }\end{array}$ & Net sample & \% of total \\
\hline Domestic Equity & 96 & 29 & 67 & $44 \%$ \\
Global Funds & 30 & 10 & 20 & $13 \%$ \\
Balanced Funds & 18 & 1 & 17 & $11 \%$ \\
Fixed Income Funds & 17 & 3 & 14 & $9 \%$ \\
Institutional Funds & $\underline{41}$ & $\underline{7}$ & $\underline{34}$ & $\underline{22 \%}$ \\
Total & 202 & 50 & 152 & $100 \%$
\end{tabular}

Note: This table reports the sample selection for SRI funds and sub-classification of SRI funds. The fund sample is obtained from the Social Investment Forum and USSIF. The final sample includes funds with data available in Morningstar as of May 2015.

We use multiple risk adjusted measures. First, the Sharpe reward to risk measure which estimates of the ratio of the average return to the standard deviation of the fund return was estimated using the equation (1) below, providing a relative gauge for portfolio comparison. Thus, given comparable portfolios, the larger the Sharpe Ratio, the better off the investor is.

$$
\mathrm{S}=\frac{R i-R f}{\sigma i}
$$

Where; $\mathrm{R}_{\mathrm{i}}$ is the return on the fund, $\mathrm{R}_{\mathrm{f}}=$ risk free rate proxied for by 30 -days US treasury bill rate, and $\sigma=$ the standard deviation of the returns of the fund.

Second, the Treynor Ratio that considers systematic risk is employed.

$$
\text { Treynor }=\frac{R i-R f}{\beta}
$$

As the Treynor Ratio uses beta as its measure of risk, it considers the systematic risk of the series, not the total risk (Treynor \& Black, 1973). This ratio is also referred to as the reward-to-volatility ratio. The third measure for assessing fund performance is the Information Ratio, defined as:

$$
\mathrm{IR}=\frac{R i-R b}{\sigma e r}
$$

Where; $R_{i}$ is the average return of fund $j$ for the specific period, $R_{b}$ is the average return for the benchmark portfolio during the period, and $\sigma_{\text {er }}$ is the standard deviation of excess return of fund $\mathrm{j}$. This ratio is used for evaluating managerial skill.

Finally, Jensen (1968)'s single market model is estimated. This measure assesses whether the fund has outperformed a market portfolio by testing whether alpha $(\alpha)$ coefficient in equation (4) is significantly different from zero. Jensen's alpha $(\alpha)$ is the difference between series realized or expected rate of return and its expected position on the security market line given his risk level. If a fund has positive Jensen's alpha, it is above the security market line, and is therefore outperforming what the CAPM would predict its performance to be.

$$
\mathrm{R}_{\mathrm{i}}-\mathrm{R}_{\mathrm{f}}=\alpha+\beta\left(\mathrm{R}_{\mathrm{M}^{-}} \mathrm{R}_{\mathrm{f}}\right)+\varepsilon
$$

Where; $R_{i}$ is the return on a fund, $\alpha$ is Jensen's alpha, $\beta$ is fund's systematic risk, $R_{f}$ is risk free rate, $R_{M}$ is a return on benchmark portfolio, and $\varepsilon$ is random error term.

\section{Empirical Results}

The analysis of performance of SRI funds relative to benchmark indices are reported in Table 2. This table includes summary statistics (mean, standard deviation, skewness, and kurtosis) of SRI funds, and benchmark indexes used. The monthly mean of 152 SRI fund is 0.6351 . The means of monthly benchmark index returns range from a low of 0.5021 for Barclays US Aggregate Bond index to a high of 0.9330 for Russell 2000 index. The results of Anova test for the equality of the means of all groups show that there are no statistically significant differences in unadjusted mean returns. The average standard deviations are also reported. The highest variation is in Russell 2000, followed 
by Russell 1000, and S\&P 500 indexes. The SRI funds have the second lowest standard deviation following Barclays US Aggregate Bond index.

Table 2. Summary statistics of performance of SRI funds and benchmarks

\begin{tabular}{lllllll}
\hline & $\begin{array}{l}\text { SRI Funds } \\
(\mathrm{n}=152)\end{array}$ & $\begin{array}{l}\text { Barclays US } \\
\text { Agg. Bond }\end{array}$ & $\begin{array}{l}\text { Russell } \\
1000\end{array}$ & $\begin{array}{l}\text { MSCI } \\
\text { World }\end{array}$ & $\begin{array}{l}\text { Russell } \\
2000\end{array}$ & $\begin{array}{l}\text { S\&P } \\
500\end{array}$ \\
\hline Mean & 0.6351 & 0.5021 & 0.8967 & 0.5292 & 0.9330 & 0.8787 \\
Std. Dev. & 4.2667 & 1.0284 & 4.3994 & 4.3738 & 5.6793 & 4.3486 \\
Skewness & 2.6924 & 1.1051 & 1.3813 & 1.7502 & 1.0921 & 1.2146 \\
Kurtosis & -0.9118 & -0.1931 & -0.7687 & -0.7971 & -0.5435 & -0.7269 \\
F-Value & 0.45 & & & & & \\
$t$-value & & 0.40 & 0.57 & 0.64 & 0.58 & 0.61 \\
\hline
\end{tabular}

Note: This table reports the summary performance statistics of SRI funds F-test is the result of Anova test used to test the null hypothesis that means of all groups are equal while T-values report the pairwise Anova test results between the monthly average returns of SRI funds and other groups. The study period spans from January 1995 to May 2015.

The analysis of unadjusted returns show that the SRI funds underperform three of the benchmark indexes, including Russell 2000, Russell 2000, and S\&P500 while overperform two of the indexes, namely Barclays US Aggregate Bond and MSCI World Index. Furthermore, pairwise Anova tests between SRI funds and benchmark indexes also show no statistically difference between unadjusted mean returns. We also see that funds have negative skewness, suggesting most values concentrate on the right of the mean, with extreme values to the left.

Table 3. Risk adjusted performance measures of SRI funds

\begin{tabular}{lllll}
\hline SRI Funds (n=152) & $\begin{array}{l}\text { Sharpe } \\
\text { Ratio }\end{array}$ & $\begin{array}{l}\text { Treynor } \\
\text { Ratio }(\%)\end{array}$ & $\begin{array}{l}\text { Jensen's Alpha } \\
(\%)\end{array}$ & $\begin{array}{l}\text { Information } \\
\text { Ratio }\end{array}$ \\
\hline Mean & 0.1452 & 0.6074 & -0.0068 & -0.0590 \\
Top 20\% & 0.3042 & 1.2493 & 0.3180 & 0.1101 \\
Bottom 20\% & 0.0361 & 0.1205 & -0.2983 & -0.2157 \\
Difference & 0.2681 & 1.1288 & 0.6163 & 0.3258 \\
t-value & $1.73^{*}$ & $2.15^{* *}$ & 1.6200 & $1.72^{*}$ \\
Benchmarks & \multicolumn{2}{l}{ Sharpe Ratio } & & \\
S\&P 500 & 0.1528 & & \\
Russell 2000 & 0.1266 & & & \\
Barclays US Agg. Bond & 0.2796 & & & \\
MSCI World & 0.0608 & & & \\
Russell 1000 & 0.1551 & & & \\
\hline
\end{tabular}

Note: This table reports various risk adjusted performance measures for the SRI funds as well as Sharpe ratios of the benchmark indices.

Most funds are also leptokurtic, showing with values lie around the mean and thicker tails, meaning a high probability for extreme values for SRI funds. In summary, the analysis of raw returns provides mixed returns with respect to SRIs performance. Table 3 provides the risk adjusted performance measures of SRI fund using five different measures. For example, the mean Sharpe Ratio of 152 SRI funds is 0.1452 with the top 20 percent of funds having an average of 0.3042 while the bottom 20 percent has 0.0361 . The difference between the top and bottom group is statistically significant. We also report the mean Treynor Ratio, Jensen's alpha, and Information Ratio for all funds as well as top and bottom 20 percent of the funds. For example, while the average Jensen's alpha is -0.0068 , indicating that SRIs funds have not earned their required returns on average as investor always desire a higher alpha. It is also noted that the difference between top and bottom 20 percent of the fund alphas are not statistically 
significant. On the other hand, for the entire sample, the Treynor Ratio is 0.6074 and Information Ratio is -0.0590 . The top and bottom 20 percent for each group are statistically different from each other.

Table 3 also reports Sharpe ratios for benchmark indexes used. These figures show that SRI funds provide comparable risk adjusted returns relative to benchmark returns. For example, S\&P500, Russell 1000, and Barclays US Agg Bond Indexes provide higher Sharpe ratios of 0.1528, 0.2796, and 0.1551 respectively than the SRI funds while Russell 2000 and MSCI World index have lower Sharpe ratios, 0.1266 and 0.0608, relative to the SRI funds.

We, then, examine the risk adjusted performances of SRI fund with respect to the types of funds, including Equity, Balanced, Fixed Income, Global, and Institutional.

Table 4. Risk adjusted performance measures based on fund types

\begin{tabular}{lllll}
\hline & Sharpe Ratio & $\begin{array}{l}\text { Treynor } \\
\text { Ratio }(\%)\end{array}$ & $\begin{array}{l}\text { Jensen's } \\
\text { Alpha }(\%)\end{array}$ & $\begin{array}{l}\text { Information } \\
\text { Ratio }\end{array}$ \\
\hline SRI Equity $(\mathrm{n}=66)$ & 0.1510 & 0.7553 & 0.0242 & -0.0468 \\
SRI Balanced (n=17) & 0.1206 & 0.4858 & -0.0812 & -0.1837 \\
t-value & $\left(1.99^{* *}\right)$ & $\left(4.43^{* * *}\right)$ & $(2.87 * * *)$ & $\left(5.08^{* * *}\right)$ \\
SRI Fixed Income (n=14) & 0.2241 & 0.3270 & 0.0029 & -0.0860 \\
t-value & $\left(3.50^{* * *}\right)$ & $\left(6.85^{* * *}\right)$ & $(-0.73)$ & $(-1.42)$ \\
SRI Global $(\mathrm{N}=21)$ & 0.0842 & 0.4881 & -0.0610 & -0.0254 \\
t-value & $\left(3.09^{* * *}\right)$ & $(2.04 * *)$ & -0.8300 & $(-0.72)$ \\
SRI Institutional $(\mathrm{n}=34)$ & 0.1516 & 0.5702 & -0.0003 & -0.0300 \\
t-value & $(0.026)$ & $\left(2.28^{* * *}\right)$ & $(-0.54)$ & $(-0.71)$ \\
F-value & $5.31^{* * *}$ & $5.16^{* * * *}$ & 0.9400 & $7.34 * * *$ \\
\hline
\end{tabular}

Note: This table reports the mean of five risk adjusted performance measures for each subgroup. Equity fund group is used as a control group for statistical comparison. F-test is the result of Anova test used to test the null hypothesis that means of all groups are equal. $\mathrm{T}$-values in parenthesis are for the test of pairwise differences in means of equity fund group and the remaining groups.

Table 4 provides risk adjusted measures for the subgroups of SRI funds. SRI Equity is used as the control group for the pairwise comparison with other subgroups. For example, SRI Equity has a Sharpe Ratio of 0.1510 and is statistically higher compared to that of SRI Balanced group with a t-value of 1.99. SRI Equity group Sharpe Ratio is statistically different than those of SRI Balanced, SRI Fixed Income, and SRI Global groups. There is no statistically significant difference between SRI Equity and SRI Institutional subgroups. SRI Equity group has statistically different risk adjusted returns relative to all subgroups, providing significantly better risk adjusted returns based on Treynor, Jensen's alpha, and Information Ratios. Similar findings are also reported for the SRI Global subgroup. The comparison to the risk adjusted measures of SRI Fixed Income, on the other hand, appears to be provided with mixed results. While the Sharpe Ratio indicates that SRI Fixed Income offers a better risk adjusted return, the Treynor Ratio supports the opposite.

Table 5 reports the analysis of individual SRI funds on Jensen's alpha and the statistical significance of alphas for the entire sample as well as subgroups. Of 152 SRI funds in the sample, 47 percent of funds experience positive alpha and only 7 percent of them is statistically significant. The remaining 53 percent of sample SRI funds have negative alpha and 18 percent of them is statistically significant. The test of significance between positive and negative SRI funds rejects the null hypothesis of no difference at 1 percent level $(\mathrm{t}$-value=11.09). Overall, only a small fraction of total SRIs have statistically significant positive alphas, indicating that many of the funds are unable to provide statistically significant positive alphas (excess returns). On the flip side, one may argue that 82 percent of the funds do not produce statistically significant negative returns. The table also displays the positive and negative alphas for each the subgroup. Negative and positive alphas slightly differ for each category. Proportionally, there appear to be more negative significant alphas for each group relative to significant positive alphas, indicating more funds do not provide excess returns. Again, one may argue that the motivation of SRI investors may not be purely superior returns, but other factors may influence the investment decision. 
Table 5. Jensen's alpha aggregate results

\begin{tabular}{|c|c|c|c|c|c|c|}
\hline & $\begin{array}{l}\# \\
\text { Positive } \\
\text { Alphas }\end{array}$ & $\begin{array}{l}\text { of } \# \text { of Positive } \\
\text { Significant } \\
\text { Alphas }\end{array}$ & $\begin{array}{l}\# \text { of } \\
\text { Negative } \\
\text { Alphas }\end{array}$ & $\begin{array}{l}\# \text { of Negative } \\
\text { Significant } \\
\text { Alphas }\end{array}$ & $\mathrm{N}$ & $\begin{array}{l}\text { Test of } \\
\text { Significance in } \\
\text { Mean (T-values) }\end{array}$ \\
\hline \multirow[t]{2}{*}{ All SRI Funds } & 71 & 10 & 81 & 28 & 152 & $(11.09 * * *)$ \\
\hline & $47 \%$ & $7 \%$ & $53 \%$ & $18 \%$ & & \\
\hline \multirow[t]{2}{*}{ SRI Equity } & 31 & 6 & 35 & 9 & 66 & $\left(9.56^{* * *}\right)$ \\
\hline & $47 \%$ & $9 \%$ & $53 \%$ & $14 \%$ & & \\
\hline \multirow[t]{2}{*}{ SRI Balanced } & 4 & 0 & 13 & 9 & 17 & $(5.36 * * *)$ \\
\hline & $24 \%$ & $0 \%$ & $76 \%$ & $53 \%$ & & \\
\hline \multirow[t]{2}{*}{ SRI Fixed Income } & 7 & 1 & 7 & 2 & 14 & $(4.42 * * *)$ \\
\hline & $50 \%$ & $7 \%$ & $50 \%$ & $14 \%$ & & \\
\hline \multirow[t]{2}{*}{ SRI Global } & 12 & 0 & 9 & 4 & 21 & $(4.20 * * *)$ \\
\hline & $57 \%$ & $0 \%$ & $43 \%$ & $19 \%$ & & \\
\hline \multirow[t]{2}{*}{ SRI Institutional } & 17 & 3 & 17 & 4 & 34 & $(5.43 * * *)$ \\
\hline & $50 \%$ & $9 \%$ & $50 \%$ & $12 \%$ & & \\
\hline
\end{tabular}

Note: This table summarizes the analysis of individual SRI funds concerning Jensen's alpha and the statistical significance of alphas. It also provides pairwise t-test for the null hypothesis of no difference in the positive and negative alphas of each subgroup

Overall, the empirical analysis shows the performance of SRI funds is not consistently better than the performance of benchmarks using various risk adjusted measures. We also find there are differences among the risk adjusted performance of subgroups of SRI funds. Bond funds perform better than both the remaining subgroups and its benchmark index. Although half of the SRI funds experience positive alpha, only 7 percent of funds provide statistically significant positive alpha to their investors. On the other hand, 18 percent of funds with negative alpha is statistically significant, implying there are more SRI funds underperforming than over performing ones.

\section{Conclusion}

SRI continues to get the attention of both practitioners and academicians as the demands for these funds increased sharply during the last decade. The questions include whether firm's objective of shareholder wealth maximization is consistent with the socially responsible behavior that society requires from the firm and whether these SRIs perform better or worse than traditional investment funds that have no restricted investment universe. Some authors question whether investors sacrifice performance for the sake of ideology.

This purpose of this study is to examine the performances of socially responsible investing in mutual funds relative to various risk adjusted benchmarks to provide additional evidence on the issue. The findings provide mixed results using risk adjusted measures. More specifically, SRI funds overperform two of the five benchmarks used in the analysis. On the other hand, using Jensen's alphas for each fund shows that only 7 percent of the SRIs funds experience statistically significant positive alphas compared to 18 percent negative alphas. Among the subgroup analyzed, only bond funds appear to provide higher risk adjusted returns to investors relative to its benchmark.

\section{References}

Adler, T. \& Kritzman, M. 2008. 'The Cost of Socially Responsible Investing.' Journal of Portfolio Management, $35(1), 52-56,6$.

Ayadi, M., Ben-Ameur, H., \& Kryzanowski, L. (2016). Typical and Tail Performance of Canadian Equity SRI Mutual Funds. Journal of Financial Services Research, 50(1), 57-94. https://doi.org/10.1007/s10693-015-0215-0

Bauer, R., Derwall, J., \& Rogér, O. (2007). The Ethical Mutual Fund Performance Debate: New Evidence from Canada. Journal of Business Ethics, 70(2), 111-124. https://doi.org/10.1007/s10551-006-9099-0 
Bauer, R., Koedijk, K., \& Otten, R. (2005). International evidence on ethical mutual fund performance and

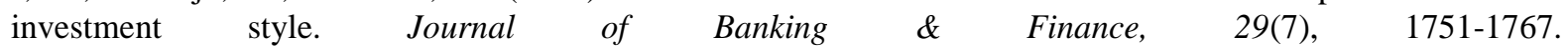
https://doi.org/10.1016/j.jbankfin.2004.06.035

Belghitar, Y., Clark, E., \& Deshmukh, N. (2017). Importance of the Fund Management Company in the Performance of Socially Responsible Mutual Funds. Journal of Financial Research, 40(3), 349-367. https://doi.org/10.1111/jfir.12127

Blanchett, D. M. (2010). Exploring the Cost of Investing in Socially Responsible Mutual Funds: An Empirical Study. The Journal of Investing(Fall), 93-103. https://doi.org/10.3905/joi.2010.19.3.093

Carhart, M. M. (1997). On persistence in mutual fund performance. The Journal of Finance, 52(1), 57-82. https://doi.org/10.1111/j.1540-6261.1997.tb03808.x

Corson, B. C., \& Van Dyck, T. (1992). Socially Responsible Investing and Financial Report: Albatross or Scapegoat? The Journal of Investing, Fall, 23-28. https://doi.org/10.3905/joi.1.2.23

DiBartolomeo, D., \& Kurtz, L. (1999). Managing Risk Exposure of Socially Screened Portfolios. Northfield Information Services Working Papers.

Diltz, J. D. (1995). The private cost of socially responsible investing. Applied Financial Economics, 5(2), 69. https://doi.org/10.1080/758529174

Fowler, S. J., \& Hope, C. (2007). A Critical Review of Sustainable Business Indices and their Impact. Journal of Business Ethics, 76(3), 243-252. https://doi.org/10.1007/s10551-007-9590-2

Gil-bazo, J., Ruiz-verdú, P., \& Santos, A. A. (2010). The Performance of Socially Responsible Mutual Funds: The Role of Fees and Management Companies. Journal of Business Ethics, 94(2), 243-263. https://doi.org/10.1007/s10551-009-0260-4

Goldreyer, E. F., Ahmed, P., \& Diltz, J. D. (1999). The performance of socially responsible mutual funds: Incorporating sociopolitical information in portfolio selection. Managerial Finance, 25(1), 23-36. https://doi.org/10.1108/03074359910765830

Gregory, A., Matatko, J., \& Luther, R. (1997). Ethical unit trust financial performance: Small company effects and fund size effects. Journal of Business Finance \& Accounting, 24(5), 705-725. https://doi.org/10.1111/1468-5957.00130

Grossman, B. R., \& Sharpe, W. F. (1986). Financial Implications of South African Divestment. Financial Analysts Journal, 42(4), 15. https://doi.org/10.2469/faj.v42.n4.15

Guerard, J. B., Jr. (1997). Additional evidence on the cost of being socially responsible in investing. Journal of Investing, 6(4), 31-36. https://doi.org/10.3905/joi.1997.408433

Hamilton, S., Jo, H., \& Statman, M. (1993). Doing well while doing good? The investment performance of socially responsible mutual funds. Financial Analysts Journal, 49(6), 62. https://doi.org/10.2469/faj.v49.n6.62

Hayes, S. K. (2005). Socially Responsible Mutual Funds: Issues to Consider When Investing with Your Conscience. Journal of Financial Service Professionals, 59(5), 59-63.

Hickman, K. A., Teets, W. R., \& Kohls, J. J. (1999). Social investing and modern portfolio theory. American Business Review, 17(1), 72-78.

Hutton, R. B., D'Antonio, L., \& Johnsen, T. (1998). Socially responsible investing: Growing issues and new opportunities. Business and Society, 37(3), 281-305. https://doi.org/10.1177/000765039803700303

Jarrow, R. A. (2010). Active Portfolio Management and Positive Alphas: Fact or Fantasy. The Journal of Portfolio Management(Summer), 17-22. https://doi.org/10.3905/jpm.2010.36.4.017

Jensen, M. C. (1968). The Performance of Mutual Funds in the Period of 1945-1964. The Journal of Finance, May, 389-416. https://doi.org/10.1111/j.1540-6261.1968.tb00815.x

Kinder, P., \& Domini, A. (1997). Social Screening: Paradigms Old and New. Journal of Investing, 6(4), 12-20. https://doi.org/10.3905/joi.1997.408443

Konar, S., \& Cohen, M. A. (2001). Does the market value environmental performance? The Review of Economics and Statistics, 83(2), 281-289. https://doi.org/10.1162/00346530151143815 
Kreander, N., Gray, R. H., Power, D. M., \& Sinclair, C. D. (2005). Evaluating the Performance of Ethical and Non-ethical Funds: A Matched Pair Analysis. Journal of Business Finance \& Accounting, 32(7/8), 1465-1493. https://doi.org/10.1111/j.0306-686X.2005.00636.x

Kurtz, L. (1997). No effect, or no net effect? Studies on socially responsible investing. Journal of Investing, 6(4), 37-49. https://doi.org/10.3905/joi.1997.37

Lin, W., Hoffman, P., \& Duncan, A. (2009). Investing in Global Equities: An Alternative Approach to Structuring Equity Portfolios. Journal of Portfolio Management, 35(2), 50-60,54,56. https://doi.org/10.3905/JPM.2009.35.2.050

Luck, C. G., \& Pilotte, N. (1993). Domini Social Index Performance. Journal of Investing, 2(3), 60-62. https://doi.org/10.3905/joi.2.3.60

Luther, R. G., \& Matatko, J. (1994). The Performance of Ethical Unit Trusts: Choosing an Approriate Benchmark. British Accounting Review, 26, 77-89. https://doi.org/10.1006/bare.1994.1007

Luther, R. G., Matatko, J., \& Corner, D. C. (1992). The Investment Performance of UK 'Ethical' Unit Trusts. Accounting, Auditing \& Accountability Journal, 5(4), 57. https://doi.org/10.1108/09513579210019521

Lyn, E. O., \& Zychowicz, E. J. (2010). The Impact of Faith-Based Screens on Investment Performance. Journal of Investing, 19(3), 136-143,138. https://doi.org/10.3905/joi.2010.19.3.136

Mallin, C. A., Saadouni, B., \& Briston, R. J. (1995). The financial performance of ethical investment funds. Journal of Business Finance \& Accounting, 22(4), 483. https://doi.org/10.1111/j.1468-5957.1995.tb00373.x

Nakai, M., Yamaguchi, K., \& Takeuchi, K. (2016). Can SRI funds better resist global financial crisis? Evidence from Japan. International Review of Financial Analysis, 48, 12-20. https://doi.org/10.1016/j.irfa.2016.09.002

Reyes, M. G., \& Grieb, T. (1998). The external performance of socially-responsible mutual funds. American Business Review, 16(1), 1-7.

Sauer, D. A. (1997). The Impact of Social-Responsibility Screens on Investment Performance: Evidence from the Domini 400 Social Index and Domini Equity Mutual Fund. Review of Financial Economics, 6(2), 137-149. https://doi.org/10.1016/S1058-3300(97)90002-1

Schueth, S. (2003). Socially responsible investing in the United States. Journal of Business Ethics, 43(3), 189. https://doi.org/10.1023/A:1022981828869

Schröder, M. (2004). The performance of socially responsible investments: Investment funds and indices. Finanzmarkt und Portfolio Management, 18(2), 122-142. https://doi.org/10.1007/s11408-004-0202-1

Statman, M. (2000). Socially Responsible Mutual Funds. Financial Analysts Journal, May/June, 30-39. https://doi.org/10.2469/faj.v56.n3.2358

Statman, M. (2006). Socially Responsible Indexes. Journal of Portfolio Management, 32(3), 100-109. https://doi.org/10.3905/jpm.2006.628411

Tippet, J. (2001). Performance of Australia's ethical funds. The Australian Economic Review, 34(2), 170-178. https://doi.org/10.1111/1467-8462.00186

Treynor, J. L., \& Black, F. (1973). How to Use Security Analysis to Improve Portfolio Selection. The Journal of Business, 46(1), 66-86. https://doi.org/10.1086/295508

Waddock, S. A., \& Graves, S. B. (1997). The Corporate Social Performance Financeial Performance Link. Strategic Management Journal, $18(4), \quad 303$. https://doi.org/10.1002/(SICI)1097-0266(199704)18:4<303::AID-SMJ869>3.0.CO;2-G

Yamashita, M., Sen, S., \& Roberts, M. C. (1999). The Rewards for Environmental Conscientiousness in the U.S. Capital Markets. Journal of Financial and Strategic Decisions, 2(1), 73-82. 